\title{
Olive response to potassium applications under different water regimes and cultivars
}

\author{
Isabel Q. Ferreira • Margarida Arrobas $(\mathbb{D} \cdot$ José Moutinho-Pereira $(\mathbb{D} \cdot$ \\ Carlos Correia $(\mathbb{D} \cdot$ M. Ângelo Rodrigues $(\mathbb{D})$
}

Received: 30 April 2018/Accepted: 17 September 2018/Published online: 20 September 2018

(C) Springer Nature B.V. 2018

\begin{abstract}
Although potassium $(\mathrm{K})$ is a macronutrient few studies have evaluated the response of olive tree to $\mathrm{K}$ fertilization. In this work results of two field and two pot $\mathrm{K}$ fertilizer experiments are presented. One of the field trials was conducted in a commercial young olive grove. The second was conducted in a plantation purposely established for this study. In the two field and the first pot experiment, the K supply was the single variation factor. The second pot experiment was arranged as a factorial with two K rates, two water regimes and two cultivars ('Arbequina' and 'Cobrançosa'). K supply did not increase olive tree growth or yield. Accumulated olive yield in the first field
\end{abstract}

I. Q. Ferreira · M. Arrobas · M. Â. Rodrigues $(\square)$ Mountain Research Centre - Polytechnic Institute of Bragança, Campus de Santa Apolónia,

5300-253 Bragança, Portugal

e-mail: isabelaqferreira@gmail.com

M. Arrobas

e-mail: marrobas@ipb.pt

M. Â. Rodrigues

e-mail: angelor@ipb.pt

J. Moutinho-Pereira · C. Correia

Centre for the Research and Technology of Agro-

Environmental and Biological Sciences (CITAB),

University of Trás-os-Montes e Alto Douro, Vila Real,

Portugal

e-mail: moutinho@utad.pt

C. Correia

e-mail: ccorreia@utad.pt experiment, for instance, varied from 2.46 and $2.84 \mathrm{~kg}$ tree ${ }^{-1}$, respectively in $\mathrm{K}$ treated and untreated plants. $\mathrm{K}$ supply increased the shoot/root ratio (1.6-2.0 from the control to the most fertilized treatment) and the concentration of $\mathrm{K}$ in roots $\left(2.9-11.2 \mathrm{~g} \mathrm{~kg}^{-1}\right)$ to a greater extent than in leaves $\left(7.0-11.9 \mathrm{~g} \mathrm{~kg}^{-1}\right)$, suggesting that shoots are a priority sink for $\mathrm{K}$ and roots may store the nutrient as a reserve. Plant water status and chlorophyll $a$ fluorescence were not significantly affected by K applications. Plants suffering from water stress yielded less phytomass (40.2-56.4 $\mathrm{g} \mathrm{pot}^{-1}$, respectively in control and well-watered plants) and showed higher $\mathrm{K}$ concentrations in leaves $\left(14.2-11.6 \mathrm{~g} \mathrm{~kg}^{-1}\right)$ and lower in roots (4.9-6.8 $\mathrm{g} \mathrm{kg}^{-1}$ ) which is probably due to the reduction of $\mathrm{K}$ uptake from the dry soil. 'Cobrançosa' appeared to be more tolerant to water stress than 'Arbequina'. These experiments showed a poor response of olive tree to $\mathrm{K}$ fertilization. Considering that $\mathrm{K}$ is usually applied by farmers every year, it seems that further studies on $\mathrm{K}$ fertilization in olive are needed in order to adjust $\mathrm{K}$ fertilizer rates to crop needs.

Keywords Chlorophyll $a$ fluorescence $\cdot$ Leaf water status · OJIP test - Olea europaea $\cdot$ Soil K status 


\section{Introduction}

Potassium plays vital functions in plants, such as enzyme activation, regulation of osmotic fluid pressure with a major impact on cell extension and stomatal aperture, and transport of photoassimilates in plant vessels (Scherer and Mengel 2007; Hawkesford et al. 2012). K appears to have a particularly positive effect on crop production under adverse conditions, inducing increased tolerance to biotic and abiotic stresses (Shabala and Pottosin 2014; Zörb et al. 2014).

In many agricultural situations the soil $\mathrm{K}$ availability is naturally low which frequently leads to the requirement for $\mathrm{K}$ fertilizer additions to increase crop yields. K response studies showing a positive effect on crop yield and/or production quality are relatively abundant, involving diverse crops and being distributed throughout the world (Pettigrew 2008; Tan et al. 2012; Qiu et al. 2014; Zhao et al. 2014). The importance of the use of $\mathrm{K}$ in agriculture has rarely been questioned. However, Khan et al. (2013), based on the analysis of the results of $2100 \mathrm{~K}$ response trials, concluded that plants rarely respond to $\mathrm{K}$ and they found 1400 studies where there was a loss of quality of production due to the application of $\mathrm{K}$.

In olive, K-response studies are not abundant. Jasrotia et al. (1999) reported a marginal increase in olive yield by the application of $\mathrm{K}$ in a 1-year trial in mature trees grown on a sandy-loam soil. Centeno and Campo (2011) report the results of a 2-year foliar K application study involving two cultivars, 'Picual' and 'Arbequina', where the plants were rainfed-managed or irrigated, respectively, in the first and the second years. The authors only report an increase in olive yield of cv. 'Arbequina' in the second year in response to the application of K. Erel et al. (2013), from an experiment carried out in containers with perlite as a substrate (perlite is a practically inert substrate) found that only after a severe and prolonged deficiency of $\mathrm{K}$ did the flowering intensity and productivity decrease. Rosati et al. (2015) showed a positive effect on fruit weight and fat content from the application of $\mathrm{N}$ and $\mathrm{K}$, which does not allow a separate evaluation of the effect of K. On the other hand, the increase in tissue K concentration by means of soil or foliar $\mathrm{K}$ applications is often found (Restrepo-Diaz et al. 2008; MoralesSillero et al. 2009; Saykhul et al. 2014).

Potassium is also the most exported element in olive, with values of about 4.5 (Fernández-Escobar
2017) to 5.5 (Rodrigues et al. 2012) $\mathrm{kg}$ per $\mathrm{Mg}$ of olives. At harvest, $\mathrm{K}$ in the fruits can represent $40 \%$ (Rodrigues et al. 2012) to 60\% (Gregoriou and ElKholy 2010) of the total $\mathrm{K}$ in the aerial biomass. Despite the relative lack of experimental data on olive tree response to $\mathrm{K}$ applications, the symptoms of deficiency are also well established and have been recorded everywhere (Freeman and Carlson 2005; Gregoriou and El-Kholy 2010; Fernández-Escobar 2017). Furthermore, $K$ is usually recommended by institutional laboratories (Therios 2009; Gregoriou and El-Kholy 2010). In Portugal, for instance, the state central laboratory (LQARS 2006) recommends 249, 187 and $124 \mathrm{~kg} \mathrm{~K} \mathrm{hm}^{-2}$ to be applied to olive on planting when $\mathrm{K}$ levels in the soil are classified, respectively, as very low, low or medium. For mature olive trees, up to $100 \mathrm{~kg} \mathrm{~K} \mathrm{hm}^{-2}$ year $^{-1}$ is recommended when the leaf $\mathrm{K}$ concentration is within the sufficiency range. However, Bourbia et al. (2013) presented a study in olive conducted on poor soils in Algeria that seems to point in another direction. The determination of $\mathrm{K}$ in the bulk soil identified seven fields with a deficiency of $\mathrm{K}$ out of a total of sixteen. Applying the same method of $\mathrm{K}$ extraction to the rhizosphere soil, only two fields showed evidence of $\mathrm{K}$ deficiency. Leaf $\mathrm{K}$ analysis also only identified two fields with leaf $\mathrm{K}$ concentrations below the sufficiency range. The authors point to the eventual role of the tree in $\mathrm{K}$ enrichment of the soil of the rhizosphere and the ability of the olive tree to develop in poor K soils. In addition, the important role of $\mathrm{K}$ in photosynthesis via regulation of stomatal conductance and opening and closing of stomata is also demonstrated in the olive tree (Arquero et al. 2006) which may mean that the nutrient has increased importance under drought conditions.

This work was motivated both by this unclear picture of the response of the olive tree to $\mathrm{K}$ applications and by the limited number of $\mathrm{K}$ fertilization studies in the olive tree, given the annual expense on $\mathrm{K}$ fertilizers that farmers usually incur. The hypothesis is that the olive tree positively responds to the application of $\mathrm{K}$. The study included field and pot experiments carried out under rainfed (field) or watered (pot) conditions and using different soils and cultivars (pots). 


\section{Materials and methods}

Study site and field and pot experiments

This study was carried out in Northeast Portugal and comprised four independent experiments: two in the field (Field1, and Field2); and two in pots (Pot1, and Pot2). The region benefits from a Mediterranean climate with some Atlantic influence, with average annual air temperature and precipitation of $12.7^{\circ} \mathrm{C}$ and $750 \mathrm{~mm}$, respectively. Average monthly air temperature and precipitation during the experimental period are shown in Fig. 1. Meteorological data reveals a long dry summer period where plants experience drought stress, usually between June and September. Some properties of the soils used in the experiments are presented in Table 1.

The Field1 was installed in March 2013 in a commercial 3-year-old olive grove of the cultivar 'Cobrançosa' spaced $7 \times 6 \mathrm{~m}$ and managed in rainfed conditions. The experimental design consisted of two treatments, with $(+\mathrm{K})$ and without $(-\mathrm{K}) \mathrm{K}$ and three replicates of each one composed of four homogeneous trees. $\mathrm{K}$ in the fertilized plots was spread in $4 \times 4 \mathrm{~m}^{2}$ with the trees at the centre of the squares. There was applied $133 \mathrm{~g} \mathrm{~K}$ tree $^{-1}$ year $^{-1}$, in the form of $\mathrm{K}$ chloride $(50 \% \mathrm{~K})$. In both $-\mathrm{K}$ and $+\mathrm{K}$ treatments a basal fertilization plan with phosphorus $(\mathrm{P})$, nitrogen (N) and boron (B) was also annually applied. P was applied at a rate of $70 \mathrm{~g} \mathrm{P}$ tree ${ }^{-1}$, as calcium superphosphate $(4 \% \mathrm{P})$. $\mathrm{N}$ and $\mathrm{B}$ were applied in smaller areas $\left(2 \times 2 \mathrm{~m}^{2}\right.$, with the tree in the centre of the square), due to their higher mobility in the soil. $\mathrm{N}$ was applied at a rate of $48 \mathrm{~g}$ tree $^{-1}$ in the form of ammonium nitrate $(34.5 \% \mathrm{~N})$ and $\mathrm{B}$ at the rate of $1.2 \mathrm{~g} \mathrm{tree}^{-1}$ as borax $(11 \% \mathrm{~B})$. Weeds were controlled by using a non-selective glyphosate-based herbicide (360 $\mathrm{g} \mathrm{L}^{-1}$ of active ingredient, $4 \mathrm{~L}$ of herbicide $\mathrm{hm}^{-2}$ ) applied once a year in early April.

Field 2 consisted of a new plantation of young trees of the cultivar 'Cobrançosa'. Young rooted plants, ca. 0.20-0.30 m high, obtained from semi-hardwood cuttings were planted in May 2014 in rows with plants spaced $1 \mathrm{~m}$ in the row and $6 \mathrm{~m}$ between rows. In the first year (July-August) the plants were watered biweekly to reduce the risk of death and then in the following years they were kept without irrigation. The experimental design consisted of two fertilizer treatments, with $(+\mathrm{K})$ and without $(-\mathrm{K}) \mathrm{K}$ and three replicates of 10 trees. In Field2, $\mathrm{K}$ in fertilized plots was applied in a rectangle of $10 \times 4 \mathrm{~m}^{2}(2 \mathrm{~m}$ for each side of the line), at a rate of $332 \mathrm{~g}$ (as $\mathrm{KCl}, 50 \% \mathrm{~K}$ ) per experimental unit and year. Annually, a basal fertilization plan with $175 \mathrm{~g} \mathrm{P}, 200 \mathrm{~g}$ of $\mathrm{N}$ and $6 \mathrm{~g} \mathrm{~B}$, was applied, the two latter nutrients in a restricted area of $20 \mathrm{~m}^{2}$ ( $1 \mathrm{~m}$ for each side of the line) per experimental unit. In the year where the young trees were planted, the soil was tilled and in the following years maintained with herbicide as in Field1.

Pot1 consisted of a $\mathrm{K}$ response trial with three $\mathrm{K}$ rates [0 (K0), $0.66(\mathrm{~K} 1)$, and $1.33(\mathrm{~K} 2) \mathrm{g} \mathrm{K} \mathrm{pot}^{-1}$ and year $^{-1}$ ] organized as a randomized block design with three blocks (three soils with different $\mathrm{K}$ status, Pot1S1, Pot1S2, Pot1S3) and six plants (6 pots) per experimental unit. The pots were filled with $3 \mathrm{~kg}$ of dry soil (sieved in $2 \mathrm{~mm}$ mesh) mixed with $5 \mathrm{~g}$ of limestone $\left(88 \% \mathrm{CaCO}_{3}, 5 \% \mathrm{MgCO}_{3}\right)$ and receiving thereafter young 'Cobrançosa' rooted cuttings, ca. $0.20 \mathrm{~m}$ high. $\mathrm{K}$ was applied as $\mathrm{KCl}(50 \% \mathrm{~K})$. In addition to $\mathrm{K}$, a basal fertilization plan was applied with $0.8 \mathrm{~g} \mathrm{~N}$ (ammonium nitrate, $34.5 \% \mathrm{~N}$ ), $0.35 \mathrm{~g} \mathrm{P}$ ( $\mathrm{P}$ fertilizer containing $1.7 \% \mathrm{P}$ ), and a mixture of
Fig. 1 Average monthly air temperature and accumulated precipitation recorded from March 2013 to March 2017 in Santa Apolónia meteorological station in Bragança

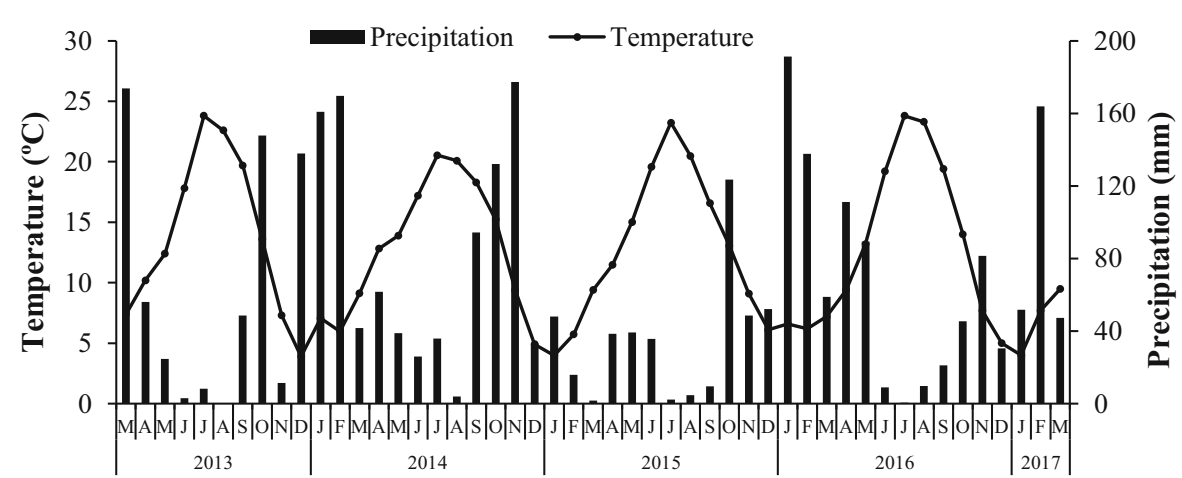


Table 1 Selected physical and chemical properties of soil samples of the field trials (Field1 and Field2), pot experiment 1 (Pot1S1, Pot1S2, and Pot1S3) and pot experiment 2 (Pot2) at the beginning of the experiments

${ }^{\mathrm{a}}$ Walkley-Black

bAmmonium lactate

${ }^{\mathrm{c}}$ Ammonium acetate

${ }^{\mathrm{d}}$ Sandy-loam

\begin{tabular}{lllllll}
\hline Soil properties & Field1 & Field2 & Pot1S1 & Pot1S2 & Pot1S3 & Pot2 \\
\hline Clay (\%) & 14.5 & 14.6 & 14.5 & 11.0 & 14.9 & 11.5 \\
Silt (\%) & 27.7 & 29.2 & 13.4 & 14.5 & 26.7 & 19.4 \\
Sand (\%) & 57.8 & 56.2 & 72.1 & 74.5 & 58.4 & 69.1 \\
Texture & S-loam & S-loam & S-loam & S-loam & S-loam & S-loam \\
pH $\left(\mathrm{H}_{2} \mathrm{O}\right)$ & 5.8 & 5.5 & 6.2 & 6.1 & 5.8 & 4.9 \\
Organic carbon $\left(\mathrm{g} \mathrm{kg}^{-1}\right)^{\mathrm{a}}$ & 8.7 & 8.7 & 6.4 & 7.4 & 12.7 & 9.5 \\
Extractable P $\left(\mathrm{mg} \mathrm{kg}^{-1}\right)^{\mathrm{b}}$ & 19.2 & 20.4 & 3.9 & 4.4 & 9.0 & 4.0 \\
Extractable K $\left(\mathrm{mg} \mathrm{kg}^{-1}\right)^{\mathrm{b}}$ & 84.6 & 94.6 & 41.5 & 48.1 & 97.9 & 44.0 \\
Exch. K $\left.(\mathrm{mmol} \mathrm{kg})^{-1}\right)^{\mathrm{c}}$ & 2.4 & 2.7 & 3.9 & 1.7 & 3.2 & 1.4 \\
Exch. Na $\left(\mathrm{mmol} \mathrm{kg}^{-1}\right)^{\mathrm{c}}$ & 3.9 & 3.6 & 3.8 & 7.2 & 6.7 & 6.7 \\
Exch. Ca $\left(\mathrm{mmol} \mathrm{kg}^{-1}\right)^{\mathrm{c}}$ & 71.6 & 84.6 & 64.7 & 62.0 & 55.1 & 46.6 \\
Exch. Mg $\left(\mathrm{mmol} \mathrm{kg}^{-1}\right)^{\mathrm{c}}$ & 22.3 & 25.6 & 37.1 & 36.0 & 33.4 & 13.9 \\
Exch. acidity $\left(\mathrm{mmol} \mathrm{kg}^{-1}\right)^{\mathrm{c}}$ & 107.2 & 118.5 & 112.5 & 122.8 & 112.3 & 90.6 \\
\hline
\end{tabular}

plants. The pots were also kept in the greenhouse. Before the beginning of each imposed water stress period, the plants of both treatments were abundantly watered and allowed to drain freely (the bottom dishes were removed) to ensure saturation and that all plants had an equivalent moisture content.

Data acquisition in the field

In Field 1 the trunk diameter was measured periodically at $0.30 \mathrm{~m}$ height and the canopy volume estimated by measuring the height of the canopy and the maximum width (NS and EW) and assuming that the canopy at this stage has an ovoid shape. The canopy volume (CV) was estimated using the equation $C V=2 / 3 \pi R^{2}(L+S)$, where $R$ is the median radius of the canopy at its widest point, $\mathrm{L}$ is the distance between the widest point and the top of the canopy (2/3 of the canopy height), and $\mathrm{S}$ is the distance between the widest point of the canopy and the base of the canopy ( $1 / 3$ of the total height of the canopy). The pruning wood was also used as an index of the growth of the trees after they had been annually pruned during the resting period. After fresh weighing, a subsample was taken to the laboratory, separated into leaves and stems, and weighed fresh, and after drying in an oven at $70{ }^{\circ} \mathrm{C}$. The subsamples were thereafter ground and analyzed for elemental composition. In early winter the olives were hand-picked and weighed separately per tree. Samples of 100 olives were weighed fresh to obtain the unit weight of the fruits. Random subsamples of 20 fruits were separated into pulp and pit and 
weighed fresh for estimating the pulp/pit ratio. After drying at $70{ }^{\circ} \mathrm{C}$, these samples were ground and analyzed for the elemental composition. In the winter resting period, and in July at the endocarp sclerification, leaf samples were taken following the standard procedure for this species (Bryson et al. 2014), dried and analyzed for the elemental composition. On October 26, 2016, soil samples were collected at three depths, $0-0.05 \mathrm{~m}, 0.05-0.10 \mathrm{~m}$ and $0.10-0.20 \mathrm{~m}$, to try to perceive the gradient in depth of soil $\mathrm{K}$ status in an experiment where the soil was kept untilled. The samples were sieved in $2 \mathrm{~mm}$ mesh, dried at $40{ }^{\circ} \mathrm{C}$ and used in the determination of several soil fertility parameters.

In Field2, young fully matured leaves were sampled twice a year, dried, ground and analyzed for elemental composition. At the end of the study, on 26 October 2016, four random plants per treatment were cut at ground level and weighed fresh. Subsamples were separated into leaves and stems, weighed fresh, oven dried and weighed dry. These samples were then ground and analyzed for the elemental composition to estimate nutrient removal.

In Pot1, the aerial part of the plants were cut ( $\sim 0.10 \mathrm{~m}$ high) at the end of the first growing season. This plant material was oven dried, separated into stems and leaves, weighed, ground and analyzed for elemental composition. At the end of the second growing season a soil sample was recovered per pot and the plant was separated into roots, stems and leaves. The root system was recovered using water under slight pressure. Soil samples were taken to the laboratory for determination of the relevant soil fertility properties. Roots, stems and leaves were oven-dried, weighed, ground and analyzed for elemental composition. Pot 2 took place over a year and the plants were cut and separated into roots, leaves and stems following the procedures reported for Pot1. A soil sample was also recovered in each pot and analyzed for several soil fertility parameters.

Leaf gas exchange was also measured in Pot 1 at midday of a summer cloudless day with and infrared gas analyser (LCpro+, ADC, Hoddesdon, UK), under greenhouse conditions. Net $\mathrm{CO}_{2}$ assimilation rate (A), stomatal conductance $\left(\mathrm{g}_{\mathrm{s}}\right)$ and transpiration rate (E) were estimated according to von Caemmerer and Farquhar (1981). Intrinsic water use efficiency was calculated as the ratio of $\mathrm{A} / \mathrm{g}_{\mathrm{s}}$. Chlorophyll $a$ fluorescence was measured on the same leaves and environmental conditions, as gas exchange, with a pulse amplitude modulated FMS 2 fluorimeter (Hansatech Instruments, Norfolk, England). Minimum fluorescence $\left(\mathrm{F}_{0}\right)$ was measured in dark adapted leaves by applying a low intensity light pulse and maximum fluorescence $\left(\mathrm{F}_{\mathrm{m}}\right)$ was measured after a saturating light pulse $\left(15,000 \mu \mathrm{mol}\right.$ photons $\left.\mathrm{m}^{-2} \mathrm{~s}^{-1}\right)$ for $0.7 \mathrm{~s}$. Maximum quantum efficiency of photosystem II (PSII) was calculated as $F_{v} / F_{m}=\left(F_{m}-F_{0}\right) / F_{m}$. After exposure for $20 \mathrm{~s}$ to actinic light, light-adapted steadystate fluorescence yield $\left(\mathrm{F}_{\mathrm{s}}\right)$ was averaged over $2.5 \mathrm{~s}$, followed by exposure to saturating light (as above) to establish $\mathrm{F}_{\mathrm{m}}{ }^{\prime}$. The effective efficiency of PSII was calculated as ФPSII $=\left(\mathrm{F}_{\mathrm{m}}{ }^{\prime}-\mathrm{F}_{\mathrm{s}}\right) / \mathrm{F}_{\mathrm{m}}{ }^{\prime}$. The apparent electron transport rate (ETR) was estimated as $\mathrm{ETR}=$ ФPSII $\times$ PPFD $\times 0.5 \times 0.84$, where PPFD is the photosynthetic photon flux density incident on the leaf, 0.5 is the factor that assumes equal distribution of energy between the two photosystems, and the leaf absorbance used was 0.84 , a common value for $\mathrm{C}_{3}$ plants (Björkman and Demmig 1987).

The OS-30p+ hand held modulated chlorophyll fluorometer was used in the field trials and in the Pot2 experiment. The OS-30p+ fluorometer is designed to measure chlorophyll $a$ fluorescence and transient fluorescence by using dark adaptation protocols $\mathrm{F}_{\mathrm{V}} /$ $\mathrm{F}_{\mathrm{M}}, \mathrm{F}_{\mathrm{V}} / \mathrm{F}_{0}$ and advanced OJIP test. $\mathrm{F}_{\mathrm{M}}, \mathrm{F}_{0}$ and $\mathrm{F}_{\mathrm{V}}$ are, respectively, maximum, minimum and variable fluorescence from dark adapted leaves, and $\mathrm{F}_{\mathrm{V}} / \mathrm{F}_{\mathrm{M} \text { - }}$ $=\left(F_{M}-F_{0}\right) / F_{M}$ and $F_{V} / F_{0}=\left(F_{M}-F_{0}\right) / F_{0}$. The OJIP test provides origin fluorescence at $20 \mu \mathrm{s}(\mathrm{O})$, fluorescence at $2 \mathrm{~ms}(\mathrm{~J})$, fluorescence at $30 \mathrm{~ms}(\mathrm{I})$ and maximum fluorescence $\left(\mathrm{P}\right.$, or $\left.\mathrm{F}_{\mathrm{M}}\right)$. The fluorometer uses a pulse modulated detection system to allow for a variety of tests, with high capability for detecting and measuring plant stress types that affect photosystem II. Measurements were taken from fully expanded young leaves, after a period of dark adaptation longer than $35 \mathrm{~min}$.

\section{Laboratory analyses}

After drying and sieving, soil samples from fields and pots, including the original samples whose results were presented in Table 1, were submitted to analytical determinations: (1) $\mathrm{pH}\left(\mathrm{H}_{2} \mathrm{O}, \mathrm{KCl}\right.$ and $\left.\mathrm{CaCl}_{2}\right)$; (2) organic carbon $(\mathrm{C})$ determined by the Walkley-Black method (easily oxidizable $\mathrm{C}$ ) and by incineration (total organic C); (3) cation exchange capacity (ammonium 
acetate, $\mathrm{pH}$ 7.0). For the determination of extractable $\mathrm{P}$ and $\mathrm{K}$, the following methods were used: (4) EgnérRiehm, consisting of the extraction of $\mathrm{P}$ and $\mathrm{K}$ with an ammonium lactate solution at $\mathrm{pH} 3.7\left(\mathrm{P}_{\mathrm{AL}}, \mathrm{K}_{\mathrm{AL}}\right)$; and (5) Mehlich 3, consisting of the extraction of $\mathrm{P}$ and $\mathrm{K}$ with a solution of ammonium nitrate, ammonium fluoride, nitric acid, EDTA, and acetic acid, $\mathrm{pH} 2.2$ $\left(\mathrm{P}_{\mathrm{M} 3}, \mathrm{~K}_{\mathrm{M} 3}\right)$. In the initial samples were also determined (6) the fractions of clay, silt and sand by the Robinson pipette method and soil classified for texture. All the above mentioned analytical methods are fully described in Houba et al. (1997).

After being dried and ground, the tissue samples (leaves, stems and roots) of all experiments were analyzed for elemental composition. The analyzes of plant tissues were performed by Kjeldahl $(\mathrm{N})$, colorimetry (B and $\mathrm{P}$ ), and atomic absorption spectrophotometry (K, Ca, Mg, Fe, Mn, Cu, Zn) methods (Walinga et al. 1989), after tissue samples were digested with nitric acid in a microwave.

An index of sclerophylly (leaf density, D) and two indices of plant water status (relative water content, RWC, and water content at saturation, WCS) were also determined. Two leaves per plant were firstly weighed to determine the fresh weight (FW) and then weighed again after they had been fully hydrated in deionized water for $48 \mathrm{~h}$ at $4{ }^{\circ} \mathrm{C}$ in the dark to determine the turgid weight (TW). Thereafter the leaves were dried in an oven at $70{ }^{\circ} \mathrm{C}$ and weighed again to determine the dry weight (DW). The three indices were estimated as: $\mathrm{D}\left(\mathrm{g} \mathrm{kg}^{-1}\right)=\mathrm{DW} / \mathrm{FW} \times$ 1000; $\mathrm{RWC} \quad(\%)=100 \times(\mathrm{FW}-\mathrm{DW}) /(\mathrm{TW}-$ DW); and WCS $\left(\mathrm{g} \mathrm{H}_{2} \mathrm{O} \mathrm{g}^{-1} \mathrm{DW}\right)=(\mathrm{TW}-\mathrm{DW}) /$ DW.

\section{Data analysis}

The data was submitted to analysis of variance. When significant differences between treatments occurred, the means were separated by the Tukey HSD test $(\alpha=0.05)$. In Pot 2 , a factorial experiment, the existence of significant interaction between treatments was evaluated. For the most relevant parameters presented in this work, no significant interaction between water regimes, $\mathrm{K}$ fertilization and cultivars were found. In some situations, to improve the understanding of the results and for graphical representation, the means were associated to mean standard deviations.

\section{Results}

Field trials

Olive yield in Field1 did not significantly vary with K application in each of the years (Table 2) or as the sum of the 3 years. Other components of the tree crop performance and the concentration of $\mathrm{K}$ in fruits separated between pulp and pit also did not vary significantly with the application of $\mathrm{K}$ to the soil, as well as the concentration of other nutrients measured in the fruits.

The increase in trunk diameter, canopy volume and pruning wood, being the three parameters used to evaluate the performance of plant growth, did not show significant differences between treatments (Fig. 2), as had occurred with the components of production.

Potassium nutritional status was evaluated throughout the experimental period by collecting leaves twice a year, during the winter resting period and at pit hardening in July. In general, there were no significant differences between treatments (Fig. 3). Leaf K levels were always above the lower limit of deficiency $\left(4 \mathrm{~g} \mathrm{~kg}^{-1}\right)$ and often above the lower limit of adequate concentrations $\left(8 \mathrm{~g} \mathrm{~kg}^{-1}\right)$. The concentration of other nutrients in the leaves, and several other relationships tested between $\mathrm{K}$ and other nutrients, particularly $\mathrm{Ca}$ and $\mathrm{Mg}$, also did not reveal significant differences between treatments (data not shown).

In contrast to all parameters determined in plants, soil $\mathrm{K}$ status significantly varied with fertilizer treatments, either determined by the ammonium lactate or ammonium acetate methods (Fig. 4). The application of $\mathrm{K}$ increased extractable $\mathrm{K}$ in the soil in comparison to the control plot. The K content in the soil decreased significantly from the shallower $(0-0.05 \mathrm{~m})$ to the deeper $(0.10-0.20 \mathrm{~m})$ layers.

The most important results recorded in Field2 are summarized in Fig. 5. The results show some differences from Field1. The application of $\mathrm{K}$ to the young plants gave significantly higher tissue $\mathrm{K}$ concentrations compared to the control (Fig. 5) at four sampling dates during the experimental period. No significant effects of the application of $\mathrm{K}$ on the concentration of other analyzed nutrients were recorded (data not shown). The application of $\mathrm{K}$ did not significantly increase the dry matter yield in the aerial part, but increased the $\mathrm{K}$ removal in the biomass due to the 
Table 2 Olive yield, selected biometric data of fruits, and pulp and pit K concentrations in three consecutive harvests (2014-2016) as a function of $\mathrm{K}$ fertilization treatments $(-\mathrm{K}$ and $+\mathrm{K})$

\begin{tabular}{|c|c|c|c|c|c|c|}
\hline & \multicolumn{2}{|l|}{2014} & \multicolumn{2}{|l|}{2015} & \multicolumn{2}{|l|}{2016} \\
\hline & $-\mathrm{K}$ & $+\mathrm{K}$ & $-\mathrm{K}$ & $+\mathrm{K}$ & $-\mathrm{K}$ & $+\mathrm{K}$ \\
\hline Olive yield $\left(\mathrm{kg}\right.$ tree $\left.{ }^{-1}\right)$ & $0.34 \mathrm{a}$ & $0.19 \mathrm{a}$ & $0.88 \mathrm{a}$ & $1.06 \mathrm{a}$ & $1.64 \mathrm{a}$ & $1.22 \mathrm{a}$ \\
\hline Fresh weight per fruit $(\mathrm{g})$ & $4.55 \mathrm{a}$ & $4.66 \mathrm{a}$ & $3.91 \mathrm{a}$ & $3.67 \mathrm{a}$ & $1.65 \mathrm{a}$ & $1.97 \mathrm{a}$ \\
\hline Pulp/pit ratio (dw) & $1.35 \mathrm{a}$ & $1.27 \mathrm{a}$ & $2.12 \mathrm{a}$ & $1.86 \mathrm{a}$ & $1.41 \mathrm{a}$ & $1.49 \mathrm{a}$ \\
\hline Pulp K $\left(\mathrm{g} \mathrm{kg}^{-1}\right)$ & $14.20 \mathrm{a}$ & $12.31 \mathrm{a}$ & $14.41 \mathrm{a}$ & $12.81 \mathrm{a}$ & $12.47 \mathrm{a}$ & $12.30 \mathrm{a}$ \\
\hline Pit $\mathrm{K}\left(\mathrm{g} \mathrm{kg}^{-1}\right)$ & $2.20 \mathrm{a}$ & $2.01 \mathrm{a}$ & $3.60 \mathrm{a}$ & $3.44 \mathrm{a}$ & $3.30 \mathrm{a}$ & $3.45 \mathrm{a}$ \\
\hline
\end{tabular}

Within each year and in lines, the same letter associated to the average values means that no significant differences between fertilizer treatments $(P<0.05)$ were found
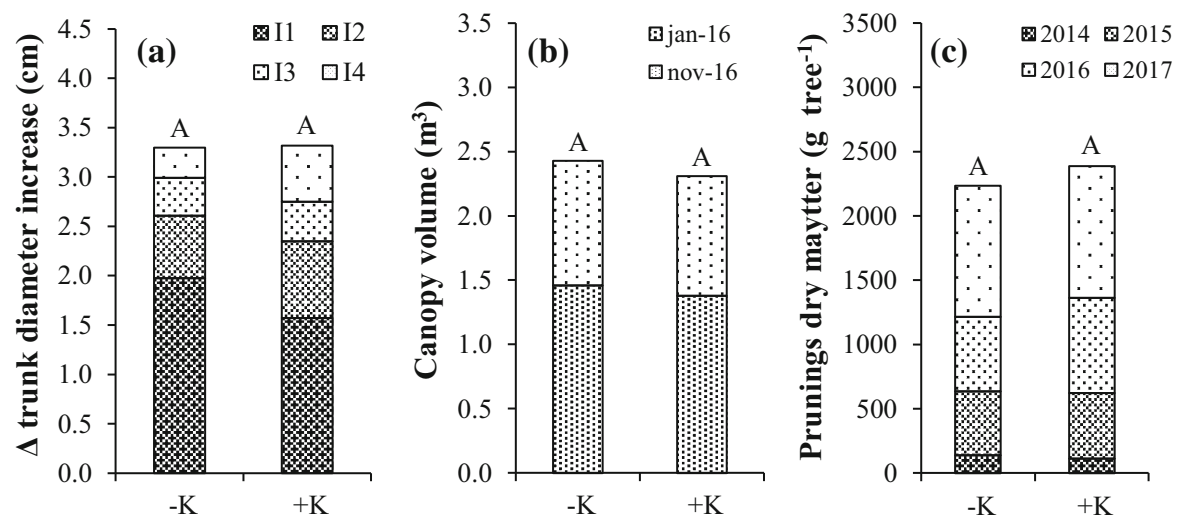

Fig. 2 a Variation $(\Delta)$ in trunk diameter increase at four consecutive intervals (I1, Jun 2013-Oct 2014; I2, Jun 2013-Jul 2015; I3, Jun 2013-Dec 2015; I4, Jun 2013-Nov 2016), b canopy volume estimated at two dates and c pruning wood obtained during the resting period of the years 2014-2017, as a

function of $\mathrm{K}$ fertilizer treatments. Capital letters above the columns is the result of the analysis of variance (no significant differences between fertilizer treatments, $P<0.05$ ) for the sum of all the records of each parameter

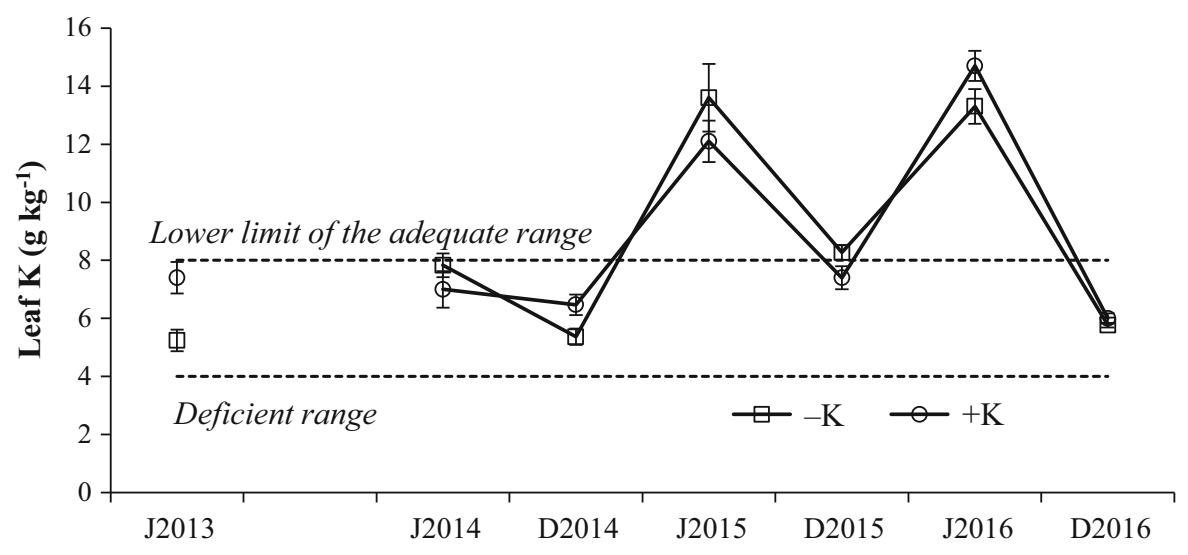

Fig. 3 Leaf K concentrations in July (J) and December (D) sampling dates in Field1. Dashed lines are the lower and upper limits of the sufficiency range established for olive. Error bars are the mean standard deviations 


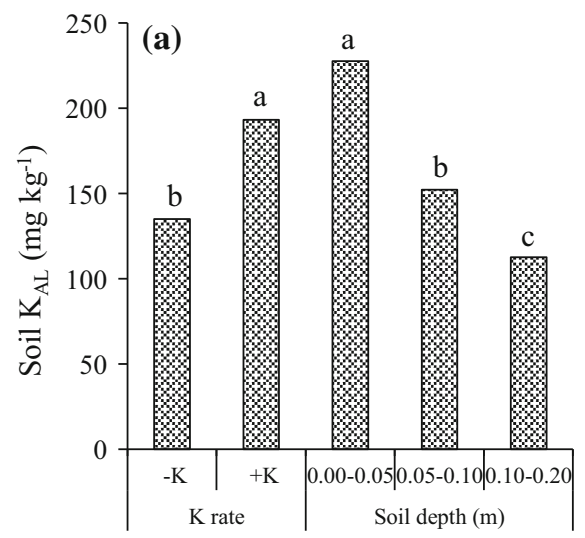

Fig. 4 Soil $\mathrm{K}$ determined by a ammonium lactate $\left(\mathrm{K}_{\mathrm{AL}}\right)$, and b ammonium acetate $\left(\mathrm{K}_{\mathrm{AA}}\right)$ as a function of fertilizer treatment $(-\mathrm{K},+\mathrm{K})$ and soil depth. Within $\mathrm{K}$ rate or soil depth group,

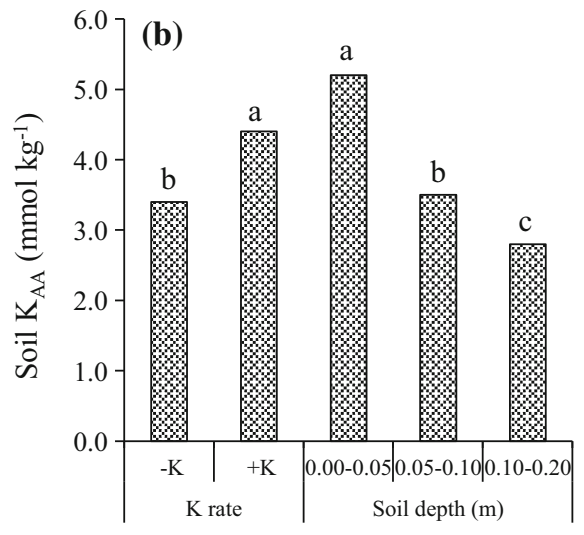

letters above the columns is the result analysis of variance and Tukey HSD test $(\alpha=0.05)$
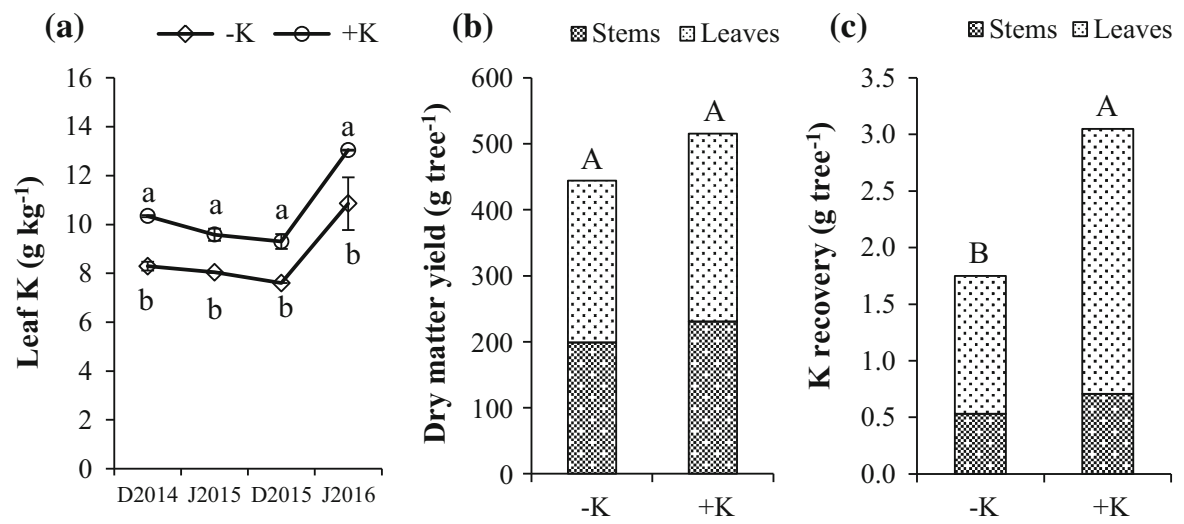

Fig. 5 a Leaf K concentration [from December (D) 2014 to July (J) 2016], b dry matter yield, and c K recovery in the above ground biomass as a function of $\mathrm{K}$ fertilizer treatments $(-\mathrm{K}$, $+K)$. Lower case letters $\mathbf{a}$ are the result of analysis of variance

and Tukey HSD test $(\alpha=0.05)$, and capital letters above the columns $\mathbf{b}$ and $\mathbf{c}$ are also the result of Tukey HSD test ( $\alpha=0.05$ ) for the sum of stems and leaves of the respective parameter

effect on the concentration of the element in the tissues.

\section{Pot experiments}

The most important results of the effect of $\mathrm{K}$ application on plants in Pot 1 are summarized in Table 3 and in Fig. 6. Leaf gas exchange and chlorophyll fluorescence data (Table 3) revealed that net photosynthetic rate, stomatal conductance, transpiration rate, maximum efficiency of photosystem II (PSII) photochemistry, effective photochemical quantum yield of PSII and electron transport rate were not significantly affected by $\mathrm{K}$ supply, while intrinsic water use efficiency was higher in $\mathrm{K} 2$ plants. In a

strictly association with the previous results, the dry matter yield in any of the plant parts, and in the whole plant, did not significantly vary with the $\mathrm{K}$ rate (Fig. 6). However, the estimation of ratios between the aerial plant parts (leaves, stems, shoots) with the roots showed that the aerial parts increased with respect to the root with the increase of applied K. Tissue K concentrations also increased significantly with the increase in $\mathrm{K}$ rate. Nevertheless, the $\mathrm{K}$ concentration in roots increased proportionally more than in shoots, being very low in the control $\mathrm{K} 0$ treatment $\left(3 \mathrm{~g} \mathrm{~kg}^{-1}\right)$ and approaching the levels in leaves in $\mathrm{K} 2$ treatment $\left(11 \mathrm{~g} \mathrm{~kg}^{-1}\right)$. The different soils used had a limited effect on the parameters determined in the plants (data not shown). 
Table 3 Net photosynthetic rate $\left(A, \mu \mathrm{mol} \mathrm{m}{ }^{-2} \mathrm{~s}^{-1}\right)$, stomatal conductance $\left(\mathrm{g}_{\mathrm{s}}, \mathrm{mmol} \mathrm{m} \mathrm{m}^{-2} \mathrm{~s}^{-1}\right)$, intrinsic water use efficiency

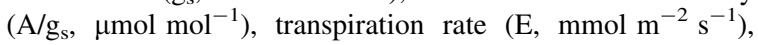
maximum efficiency of PSII photochemistry $\left(\mathrm{F}_{\mathrm{v}} / \mathrm{F}_{\mathrm{M}}\right)$, effective

\begin{tabular}{llllllll}
\hline Treatment & $\mathrm{A}$ & $\mathrm{g}_{\mathrm{s}}$ & $\mathrm{A} / \mathrm{g}_{\mathrm{s}}$ & $\mathrm{E}$ & $\mathrm{F}_{\mathrm{V}} / \mathrm{F}_{\mathrm{M}}$ & कPSII & ETR \\
\hline K0 & $11.87 \mathrm{a}$ & $233.1 \mathrm{a}$ & $53.2 \mathrm{~b}$ & $4.42 \mathrm{a}$ & $0.817 \mathrm{a}$ & $0.450 \mathrm{a}$ & $91.3 \mathrm{a}$ \\
K1 & $13.13 \mathrm{a}$ & $241.4 \mathrm{a}$ & $55.2 \mathrm{~b}$ & $4.55 \mathrm{a}$ & $0.821 \mathrm{a}$ & $0.468 \mathrm{a}$ & $98.4 \mathrm{a}$ \\
$\mathrm{K} 2$ & $13.42 \mathrm{a}$ & $197.1 \mathrm{a}$ & $68.3 \mathrm{a}$ & $4.10 \mathrm{a}$ & $0.821 \mathrm{a}$ & $0.472 \mathrm{a}$ & $98.9 \mathrm{a}$ \\
\hline
\end{tabular}

In columns, means followed by the same letter are not significantly different by Tukey HSD test $(\alpha=0.05)$
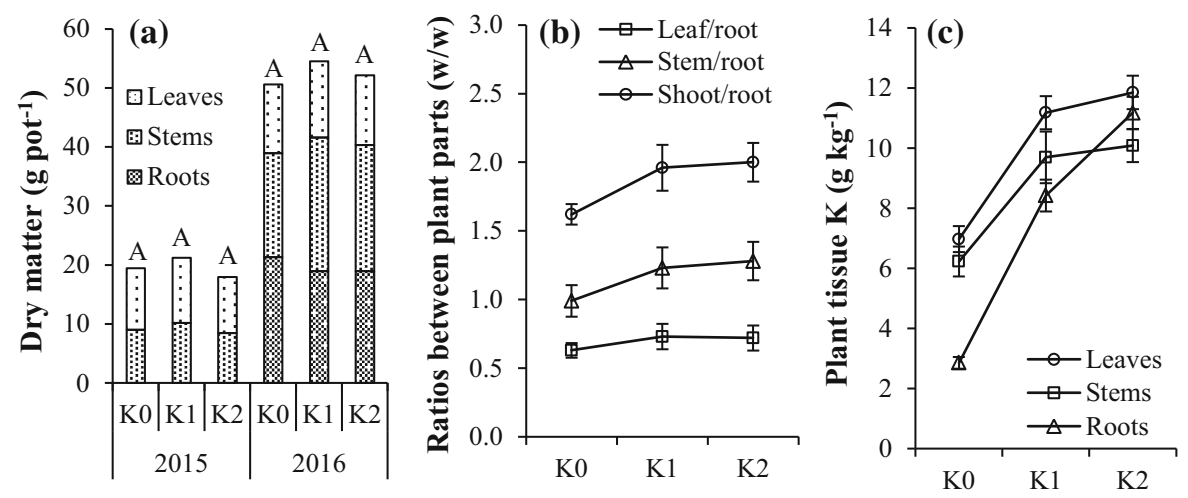

Fig. 6 a Dry matter yield, b ratios between plant parts, and c plant tissue $\mathrm{K}$ as a function of $\mathrm{K}$ fertilizer treatment. Capital letters $\mathbf{a}$ are the result of analysis of variance within each year for

In Pot1 the application of $\mathrm{K}$ to the soil significantly increased soil $\mathrm{K}$ status when evaluated by three different methods (Table 4). There were also found to be significant differences between soils (blocks in this experiment) reflecting the original differences at sampling time between the soils.

In Pot 2 the water stress imposed by the experimental design significantly reduced the dry matter yield in all plant parts in comparison to the well-watered plants

Table 4 Soil $\mathrm{K}$ status as a function of $\mathrm{K}$ fertilizer treatment determined by ammonium lactate $\left(\mathrm{K}_{\mathrm{AL}}\right)$, Mehlich $3\left(\mathrm{~K}_{\mathrm{M} 3}\right)$ and ammonium acetate $\left(\mathrm{K}_{\mathrm{AA}}\right)$ methods

\begin{tabular}{llll}
\hline K rate & $\begin{array}{l}\mathrm{K}_{\mathrm{AL}} \\
\left(\mathrm{mg} \mathrm{kg}^{-1}\right)\end{array}$ & \multicolumn{1}{c}{$\mathrm{K}_{\mathrm{M} 3}$} & $\begin{array}{l}\mathrm{K}_{\mathrm{AA}} \\
\left(\mathrm{mmol} \mathrm{kg}^{-1}\right)\end{array}$ \\
\hline $\mathrm{K} 0$ & $79.1 \mathrm{c}$ & $58.5 \mathrm{c}$ & $4.4 \mathrm{c}$ \\
$\mathrm{K} 1$ & $150.9 \mathrm{~b}$ & $123.7 \mathrm{~b}$ & $6.0 \mathrm{~b}$ \\
$\mathrm{~K} 2$ & $236.1 \mathrm{a}$ & $256.3 \mathrm{a}$ & $9.8 \mathrm{a}$ \\
\hline
\end{tabular}

In columns, means followed by the same letter are not significantly different by Tukey HSD test $(\alpha=0.05)$ photochemical quantum yield of PSII ( $\Phi$ PSII) and electron transport rate (ETR, $\mu \mathrm{mol} \mathrm{e}^{-} \mathrm{m}^{-2} \mathrm{~s}^{-1}$ ) as a function of $\mathrm{K}$ fertilizer treatment 

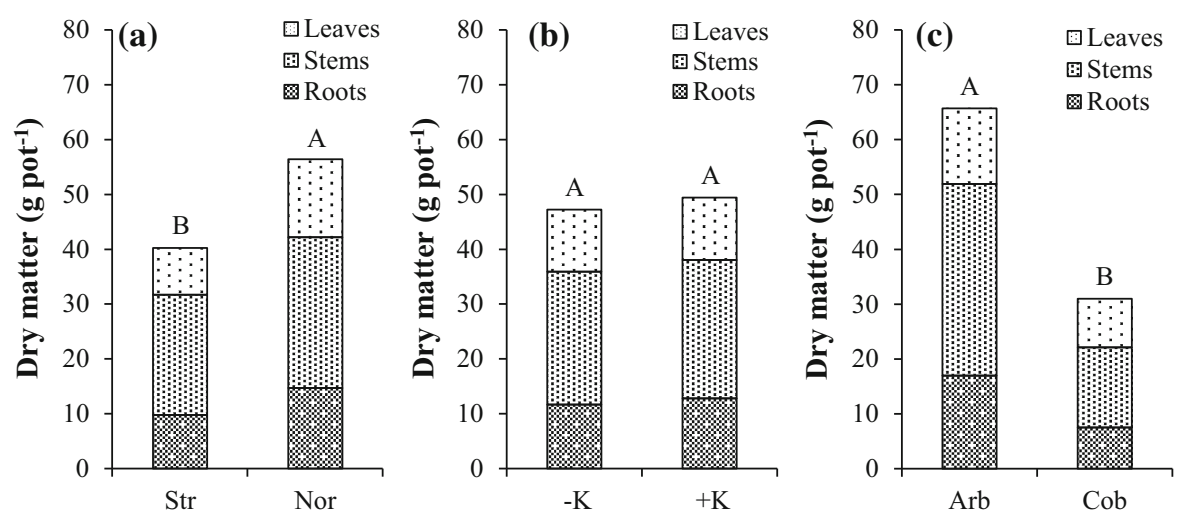

Fig. 7 Dry matter yield in the different plant parts as a function of a water regime (Stress, Str or Normal, Nor), b fertilizer treatment $(-\mathrm{K}$ or $+\mathrm{K})$, and c cultivar ('Arbequina', Arb or
'Cobrançosa', Cob). Capital letters above the columns is the result of analysis of variance and Tukey HSD test $(\alpha=0.05)$ for the sum of the plant parts

Table 5 Tissue $\mathrm{K}$ concentration and soil $\mathrm{K}$ status as a function of water regime (stress, normal), fertilizer treatment $(-\mathrm{K}$, $+\mathrm{K})$, and cultivar ('Arbequina', 'Cobrançosa')

\begin{tabular}{|c|c|c|c|c|c|c|}
\hline \multirow[t]{2}{*}{ Treatment } & \multicolumn{3}{|c|}{ Tissue K concentration } & \multicolumn{3}{|c|}{ Soil K status } \\
\hline & $\begin{array}{l}\text { Leaves } \\
\mathrm{g} \mathrm{kg}^{-1}\end{array}$ & Stems & Roots & $\begin{array}{l}\mathrm{K}_{\mathrm{AL}} \\
\mathrm{mg} \mathrm{kg}^{-1}\end{array}$ & $\mathrm{~K}_{\mathrm{Me} 3}$ & $\begin{array}{l}\mathrm{K}_{\mathrm{AA}} \\
\mathrm{mmol} \mathrm{kg}\end{array}$ \\
\hline Stress & $14.2 \mathrm{a}$ & $11.6 \mathrm{a}$ & $4.9 \mathrm{~b}$ & 86.9 a & $70.0 \mathrm{a}$ & $2.85 \mathrm{a}$ \\
\hline Normal & $11.6 \mathrm{~b}$ & $8.3 \mathrm{~b}$ & $6.8 \mathrm{a}$ & $67.4 \mathrm{~b}$ & $58.9 \mathrm{~b}$ & $2.67 \mathrm{~b}$ \\
\hline$-\mathrm{K}$ & $11.3 \mathrm{~b}$ & $8.9 \mathrm{~b}$ & $4.1 \mathrm{~b}$ & $64.2 \mathrm{~b}$ & $50.5 \mathrm{~b}$ & $2.45 \mathrm{~b}$ \\
\hline$+\mathrm{K}$ & $14.5 \mathrm{a}$ & $11.0 \mathrm{a}$ & $7.6 \mathrm{a}$ & $90.1 \mathrm{a}$ & $78.4 \mathrm{a}$ & $3.07 \mathrm{a}$ \\
\hline Arbequina & $13.6 \mathrm{a}$ & $10.7 \mathrm{a}$ & $5.7 \mathrm{a}$ & $78.0 \mathrm{a}$ & $63.8 \mathrm{a}$ & $2.73 \mathrm{a}$ \\
\hline Cobrançosa & $12.3 \mathrm{~b}$ & $9.2 \mathrm{~b}$ & $6.0 \mathrm{a}$ & $76.3 \mathrm{a}$ & $65.1 \mathrm{a}$ & $2.79 \mathrm{a}$ \\
\hline
\end{tabular}

In columns, within each variation factor, means followed by the same letter are not significantly different by Tukey HSD test $(\alpha=0.05)$

Leaf D, usually seen as an index of sclerophylly, greatly increased in water-stressed plants over the periods without irrigation (Fig. 8). No significant differences were found in $\mathrm{D}$ due to $\mathrm{K}$ supply and cultivar. Leaf RWC deeply decreased during the water-stress periods in water-stressed plants. The addition of $\mathrm{K}$ did not influence the RWC of the leaves. 'Arbequina' leaves showed RWC values lower than those of 'Cobrançosa' but the difference did not increase over the water-stressed periods. Leaf WCS decreased in water-stressed plants during the cycles without irrigation. The effect of K supply was not significant, and 'Arbequina' showed higher leaf WCS than 'Cobrançosa', but the differences between the two cultivars did not increase during the waterstressed periods.
Selected direct measurements and estimated chlorophyll $a$ fluorescence parameters from the reading of 12 July 2015, the one that was performed furthest from the beginning of the corresponding water-stressed period, are shown in Table 6. The other sampling dates displayed results with a similar trend (data not shown). Water stress had a significant influence on all measured and estimated parameters. Average $F_{0}$ values were lower in the plants not subjected to water stress while all the other parameters were found to be lower in water-stressed plants. K supply had no influence on any of the parameters related to chlorophyll $a$ fluorescence and OJIP fluorescence transient. Average $F_{V} / F_{M}$ and $F_{V} / F_{0}$ ratios were found significantly higher for the 'Cobrançosa' 

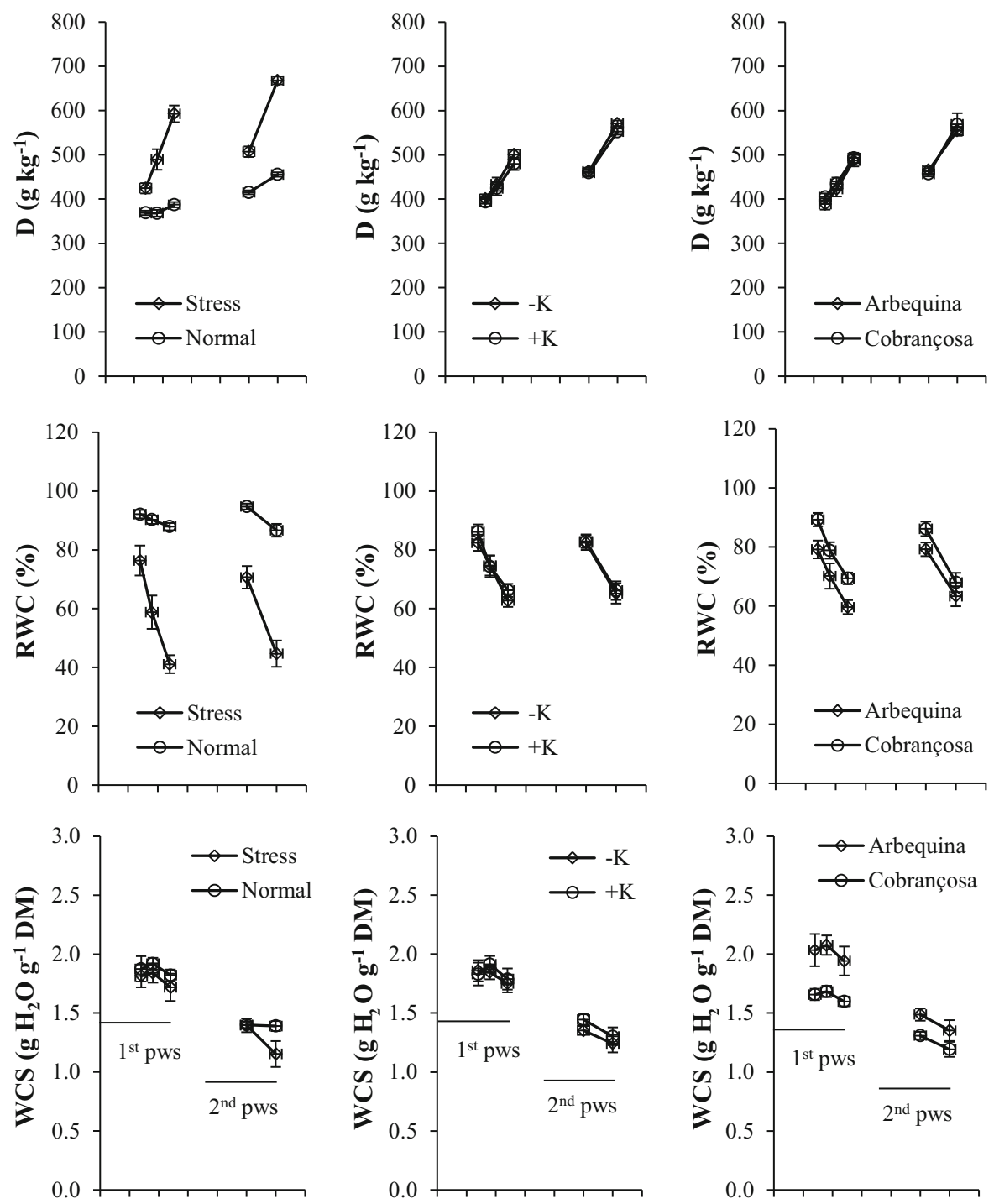

Fig. 8 Density of foliar tissue (D), relative water content (RWC), and water content of saturated leaves (WCS), as a function of water regime, $\mathrm{K}$ fertilizer treatment and cultivar. First period of water stress (1st pws), starting June 29th with

cultivar in comparison to 'Arbequina', whereas average $\mathrm{O}$ and $\mathrm{F}_{0}$ showed contrary trends.

\section{Discussion}

From Field1, no positive response was obtained to the application of $\mathrm{K}$ in olive yields and tree crop performance, as well as in leaf $\mathrm{K}$ concentrations, although a significant increase in soil $\mathrm{K}$ levels was readings taken at 7 th, 9 th, and 12 th July. Second period of water stress (2nd pws), starting August 19th with readings taken at 31 st August and 5th September. Error bars are the mean standard deviations

obtained. In Field 2 there was no increase in dry matter yield, but leaf $\mathrm{K}$ concentrations increased, which also caused an increase in $\mathrm{K}$ removal from the aerial biomass. These results seem to support the thesis of Khan et al. (2013), who stated that it is difficult to obtain, under field conditions, a response to the application of $\mathrm{K}$, and also the results of Erel et al. (2013), who found a decrease in flowering intensity and productivity in olive only when a severe deficiency was imposed by growing the plants in 
Table 6 Selected direct readout and estimated chlorophyll $a$ fluorescence and OJIP fluorescence transient parameters from the reading of 12 July 2016 performed 14 days after the beginning of the drying cycle

\begin{tabular}{|c|c|c|c|c|c|c|c|}
\hline Treatment & $\mathrm{O}$ & $\mathbf{J}$ step & I step & $P$ step $\left(F_{M}\right)$ & F0 & $\mathrm{F}_{\mathrm{V}} / \mathrm{F}_{\mathrm{M}}$ & $\mathrm{F}_{\mathrm{V}} / \mathrm{F}_{0}$ \\
\hline Stress & $359.6 \mathrm{a}$ & $497.8 \mathrm{~b}$ & $705.9 \mathrm{~b}$ & $792.3 \mathrm{~b}$ & $263.7 \mathrm{a}$ & $0.650 \mathrm{~b}$ & $2.11 \mathrm{~b}$ \\
\hline Normal & $338.4 \mathrm{a}$ & $581.4 \mathrm{a}$ & $1016.1 \mathrm{a}$ & $1178.8 \mathrm{a}$ & $213.9 \mathrm{~b}$ & $0.818 \mathrm{a}$ & $4.53 \mathrm{a}$ \\
\hline$-\mathrm{K}$ & $340.1 \mathrm{a}$ & $529.1 \mathrm{a}$ & $848.4 \mathrm{a}$ & $971.3 \mathrm{a}$ & $234.6 \mathrm{a}$ & $0.724 \mathrm{a}$ & $3.35 \mathrm{a}$ \\
\hline$+\mathrm{K}$ & 357.9 a & $549.8 \mathrm{a}$ & $873.6 \mathrm{a}$ & 999.7 a & $242.9 \mathrm{a}$ & $0.744 \mathrm{a}$ & $3.29 \mathrm{a}$ \\
\hline Arbequina & $374.2 \mathrm{a}$ & $545.4 \mathrm{a}$ & 823.9 a & $938.4 \mathrm{a}$ & $253.0 \mathrm{a}$ & $0.676 \mathrm{~b}$ & $2.79 \mathrm{~b}$ \\
\hline Cobrançosa & $323.7 \mathrm{~b}$ & $533.8 \mathrm{a}$ & $898.1 \mathrm{a}$ & $1036.3 \mathrm{a}$ & $215.5 \mathrm{~b}$ & $0.791 \mathrm{a}$ & $3.85 \mathrm{a}$ \\
\hline
\end{tabular}

In columns, within each variation factor, means followed by the same letter are not significantly different by Tukey HSD test $(\alpha=0.05)$

$\mathrm{O}$ (origin), fluorescence value at $20 \mu \mathrm{s}$; J step, fluorescence value at $2 \mathrm{~ms}$; I step, fluorescence value at $30 \mathrm{~ms}$; P step (FM), maximum fluorescence; $\mathrm{F}$, pre-photosynthetic minimum fluorescence; $\mathrm{F}_{\mathrm{V}} / \mathrm{F}_{\mathrm{M}}$, ratio of variable fluorescence to maximal fluorescence; $\mathrm{F}_{\mathrm{V}} / \mathrm{F}_{0}$, variable fluorescence normalized to minimum fluorescence

containers with perlite and without $\mathrm{K}$ application. Previous studies carried out in the region with other crops, in field and in pots, revealed also that is difficult to obtain a positive response in crop growth or yield to the application of K (Arrobas et al. 2017; Afonso et al. 2018). In these experiments, probably soil $\mathrm{K}$ levels and leaf $\mathrm{K}$ concentrations were never low enough even in control treatment to significantly affect the performance of the trees. The field and pot trials collectively did not reveal significant variation in the concentration of other nutrients in the tissues following the application of $\mathrm{K}$.

Potassium application increased $\mathrm{K}$ concentration in leaves, stems and roots with the exception of Field1. In none of the experiments was it possible to observe an increase in dry matter yield due to $\mathrm{K}$ application, including the pot experiments. However, the application of K increased the shoot/root ratio. Similar results were reported previously for different macronutrients, including $\mathrm{K}$, mediated by effects on protein synthesis (Andrews et al. 1999). Pot experiments also showed that the $\mathrm{K}$ concentration in the roots was lower than in the shoots for low $\mathrm{K}$ levels in the soil, but as the availability of $\mathrm{K}$ in the soil increased the concentration of $\mathrm{K}$ in the roots increased more than in the shoots, reaching values close to those of the leaves. These results seem to indicate that the shoots are a priority sink for $\mathrm{K}$ and that the roots can act as a reservoir when the soil $\mathrm{K}$ availability is high. The role of $\mathrm{K}$ in photosynthesis, stomatal regulation, protein synthesis and transport of photoassimilates (Scherer and Mengel 2007; Hawkesford et al. 2012; Zörb et al. 2014) may justify the higher $\mathrm{K}$ concentration in the aboveground plant parts. Meanwhile, the higher intrinsic water use efficiency observed in K2 plants has major importance, as can contribute to increase olive tree tolerance to temporary water shortage.

$\mathrm{K}$ showed no significant effect on D, RWC and WCS. K also showed no significant effect on parameters related to leaf gas exchange, chlorophyll $a$ fluorescence and OJIP fluorescence transient. Once again, the results may be justified by the fact that $\mathrm{K}$ deficiency in these experiments was not acute enough to affect relevant physiological processes in the plants.

Pot2 revealed that water stress reduced plant dry matter yield. In drought conditions, the reduction of water availability limits the opening of stomata affecting plant growth and biomass accumulation as observed by Bacelar et al. (2007) in three olive cultivars. Under water stress, the concentration of $\mathrm{K}$ increased in the shoots (stems and leaves) but was reduced significantly in the roots. Under drought, plants channeled more $\mathrm{K}$ to the aerial part given its role in the regulation of the stomatal function and cell water relations (Shabala and Pottosin 2014; Zörb et al. 2014) thereby reducing the $K$ concentration in roots. On the other hand, the reduction of soil moisture restricts the movement of $\mathrm{K}$ to the roots by diffusion, and the reduction of plant transpiration decreases the movement of $\mathrm{K}$ to the roots by mass flow (Havlin et al. 2014). Thus, K uptake probably could not compensate the amount of $\mathrm{K}$ that was sent to the shoots, thereby reducing the $\mathrm{K}$ concentration in the roots. Meanwhile, water stress increased $\mathrm{D}$ in order to counteract the 
inadequate water status, as indicated by the lower RWC. Several studies have also shown a decrease in RWC with increasing water stress (Boughalleb and Hajlaoui 2011; Ghahfarokhi et al. 2015; Zegaoui et al. 2017). Water stress can increase D since reductions in turgor pressure and cell expansion result in the same dry mass within a smaller leaf area (Peña-Rojas et al. 2005). The increase in $D$ was an acclimation response to lower water availability, as leaves with high tissue density are better able to survive a severe drought because of a higher resistance to physical damage induced by desiccation (Mediavilla et al. 2001). Moreover, water stress severely reduced $\mathrm{F}_{\mathrm{V}} / \mathrm{FM}$ and $\mathrm{F}_{0} / \mathrm{F}_{\mathrm{M}}$ and all points of the OJIP curves with the exception of origin $(\mathrm{O})$ fluorescence value at $20 \mu \mathrm{s}$, whereas increased significantly the minimal fluorescence $\left(\mathrm{F}_{0}\right)$. Thus, water stress had a marked negative effect on the photochemical reactions of photosynthesis, in agreement with the results obtained in other studies (Boughalleb and Hajlaoui 2011; Gomes et al. 2012; Jedmowski et al. 2013), what contribute to the reduction of dry matter yield observed in the plants submitted to drought stress. In addition, in nonirrigated pots, soil temperature probably increased which may have contributed to the reduction in RWC and dry matter yield as observed by BenllochGonzález et al. (2016).

'Arbequina' produced more phytomass than 'Cobrançosa'. Arbequina plants were slightly more vigorous at planting and this may have given them some advantage, although they had been trimmed by pruning. On the other hand, 'Arbequina' is an early maturing cv. (Barranco 2017) compared to 'Cobrançosa', which may help to justify its higher dry matter yield. 'Arbequina' showed K concentrations significantly higher than 'Cobrançosa' in the shoots and tendentially lower in the root. 'Arbequina', being an early maturing $\mathrm{cv}$. with a higher growth rate, may require more $\mathrm{K}$ in the shoot, leading to a reduction of the nutrient in the root since the availability of $\mathrm{K}$ in the soil is similar. The cultivars showed no differences in $\mathrm{D}$, but 'Arbequina' showed lower RWC and higher WCS values than 'Cobrançosa', an expected result considering that 'Arbequina' is a cultivar less adapted to water stress. Previous studies by Bacelar et al. (2004) showed that 'Arbequina' had lower RWC and higher WCS than 'Cobrançosa', indicating higher water loss of the former. In other studies with different olive tree genotypes, Bacelar et al. $(2006,2007)$ found
'Cobrançosa' a very promising cv. for cultivation in semi-arid areas. 'Arbequina' showed lower values of $\mathrm{F}_{\mathrm{V}} / \mathrm{F}_{\mathrm{M}}$ and $\mathrm{F}_{\mathrm{V}} / \mathrm{F}_{0}$ than 'Cobrançosa', indicating a greater disadvantage under water stress, as verified also by Bacelar et al. (2004).

\section{Conclusions}

The applied $\mathrm{K}$ did not have a significant effect on the performance of the trees, evaluated by the dry matter yield, leaf water status or parameters associated with the chlorophyll $a$ fluorescence, which apparently reduce the importance of $\mathrm{K}$ fertilization in these soils. The application of $\mathrm{K}$ increased the shoot/root ratio, and proportionally increased the $\mathrm{K}$ concentration in the root, indicating that the shoot is a priority sink for $\mathrm{K}$ and that $\mathrm{K}$ in the root may act as a reserve to the plant when uptake is limited. The water stress reduced dry matter yield and the level of $\mathrm{K}$ in the root which might be due to the reduced $\mathrm{K}$ uptake and the priority given to the shoot to the $\mathrm{K}$ available in the plant. 'Arbequina' showed greater sensitivity to water stress than 'Cobrançosa' but presented higher dry matter yield in well-watered conditions possibly because it is an earlier maturing cultivar.

Acknowledgements The authors are grateful to the Foundation for Science and Technology (FCT, Portugal) and FEDER under Programme PT2020 for financial support to CIMO (UID/AGR/00690/2013). The work was also funded by the INTERACT Project- "Integrative Research in Environment, Agro-Chains and Technology", No. NORTE01-0145-FEDER-000017, in its line of research entitled ISAC, co-financed by the European Regional Development Fund (ERDF) through NORTE 2020 (North Regional Operational Program 2014/2020). For authors integrated in the CITAB research centre, it was further financed by the FEDER/ COMPETE/POCI-Operational Competitiveness and Internationalization Programme, under Project POCI-01-0145FEDER-006958, and by National Funds of FCT-Portuguese Foundation for Science and Technology, under the Project UID/ AGR/04033/2013.

\section{References}

Afonso S, Arrobas M, Ferreira IQ, Rodrigues MA (2018) Leaf nutrient concentration standards for lemon verbena (Aloysia citrodora Paláu) obtained from field and pot fertilization experiments. J Appl Res Med Aromat Plants 8:33-40

Andrews M, Sprent JI, Raven JA, Eady PE (1999) Relationships between shoot to root ratio, growth and leaf soluble protein 
concentration of Pisum sativum, Phaseolus vulgaris and Triticum aestivum under different nutrient deficiencies. Plant Cell Environ 22:949-958

Arquero O, Barranco D, Benlloch M (2006) Potassium starvation increases stomatal conductance in olive trees. HortScience 41(2):433-436

Arrobas M, Afonso S, Ferreira IQ, Moutinho-Pereira J, Correia C, Rodrigues MA (2017) Liming and application of nitrogen, phosphorus, potassium and boron on a young plantation of chestnut. Turk J Agric For 41:441-451

Bacelar EA, Correia CM, Moutinho-Pereira JM, Gonçalves BC, Lopes JI, Torres-Pereira JM (2004) Sclerophylly and leaf anatomical traits of five field-grown olive cultivars growing under drought conditions. Tree Physiol 24:233-239

Bacelar EA, Santos DL, Moutinho-Pereira JM, Gonçalves BC, Ferreira HF, Correia CM (2006) Immediate responses and adaptative strategies of three olive cultivars under contrasting water availability regimes: changes on structure and chemical composition of foliage and oxidative damage. Plant Sci 170:596-605

Bacelar EA, Moutinho-Pereira JM, Gonçalves BC, Ferreira HF, Correia CM (2007) Changes in growth, gas exchange, xylem hydraulic properties and water use efficiency of three olive cultivars under contrasting water availability regimes. Environ Exp Bot 60:183-192

Barranco D (2017) Variedades y patrones. In: Barranco D, Fernández-Escobar R, Rallo L (eds) El cultivo del olivo, 7th edn. Ediciones Mundi-Prensa, Madrid, pp 63-95

Benlloch-González M, Quintero JM, Suárez MP, Sánchez-Lucas R, Fernández-Escobar R, Benlloch M (2016) Effect of moderate high temperature on the vegetative growth and potassium allocation in olive plants. J Plant Physiol 207:22-29

Björkman O, Demmig B (1987) Photon yield of $\mathrm{O}_{2}$ evolution and chlorophyll fluorescence characteristics at $77 \mathrm{~K}$ among vascular plants of diverse origins. Planta 170:489-504

Boughalleb F, Hajlaoui H (2011) Physiological and anatomical changes induced by drought in two olive cultivars (cv Zalmati and Chemlali). Acta Physiol Plant 33:53-65

Bourbia SM, Barré P, Kaci MBN, Derridj A, Velde B (2013) Potassium status in bulk and rhizospheric soils of olive groves in North Algeria. Geoderma 197(198):161-168

Bryson G, Mills HA, Sasseville DN, Jones JB Jr, Barker AV (2014) Plant analysis handbook III. A guide to sampling, preparation, analysis and interpretation for agronomic and horticultural crops. Micro-Macro Publishing, Inc, Athens

Centeno A, Campo MG (2011) Response of mature olive trees with adequate leaf nutrient status to additional nitrogen, phosphorus and potassium fertilization. Acta Hortic 888:277-280

Erel R, Yermiyahu U, Van Opstal J, Ben-Gal A, Schwartz A, Dag A (2013) The importance of olive (Olea europaea L.) tree nutritional status on its productivity. Sci Hortic 159:8-18

Fernández-Escobar R (2017) Fertilization. In: Barranco D, Fernández-Escobar R, Rallo L (eds) El cultivo del olivo, 7th edn. Ediciones Mundi-Prensa, Madrid, pp 419-460

Freeman M, Carlson RM (2005) Mineral nutrient availability. In: Sibbett GS, Ferguson L (eds) Olive production manual, 2nd edn. University of California Publication, Oakland, pp 75-82
Ghahfarokhi MG, Mansurifar S, Taghizadeh-Mehrjardi R, Saeidi M, Jamshidi AM, Ghasemi E (2015) Effects of drought stress and rewatering on antioxidant systems and relative water content in different growth stages of maize (Zea mays L.) hybrids. Arch Agron Soil Sci 61(4):493-506

Gomes MTG, Luz AC, Santos MR, Batitucci MCP, Silva DM, Falqueto AR (2012) Drought tolerance of passion fruit plants assessed by the OJIP chlorophyll a fluorescence transient. Sci Hortic 142:49-56

Gregoriou C, El-Kholy M (2010) Fertilization. In: Olive GAP manual: good agricultural practices for the Near East and North Africa countries. FAO, Rome

Havlin JL, Tisdale SL, Nelson WL, Beaton JD (2014) Soil fertility and fertilizers, an introduction to nutrient management, 8th edn. Pearson, Boston

Hawkesford M, Horst W, Kichey T, Lambers H, Schjoerring J, Moller IS, White P (2012) Function of macronutrients. In: Marschner P (ed) Marschner's mineral nutrition of higher plants. Elsevier, London, pp 135-189

Houba VJG, van der Lee JJ, Novozamsky I (1997) Soil analysis procedures. Other procedures. Landbouwuniversiteit, Wagningen

Jasrotia A, Singh RP, Singh JM, Bhutami VP (1999) Response of olive trees to varying levels of $\mathrm{N}$ and $\mathrm{K}$ fertilizers. Acta Hortic 474:337-340

Jedmowski C, Ashoub A, Brüggemann W (2013) Reactions of Egyptian landraces of Hordeum vulgare and Sorghum bicolor to drought stress, evaluated by the OJIP fluorescence transient analysis. Acta Physiol Plant 35:345-354

Khan SA, Mulvaney RL, Ellsworth TR (2013) The potassium paradox: implications for soil fertility, crop production and human health. Renew Agric Food Syst 29(1):3-27

LQARS (Laboratório Químico Agrícola Rebelo da Silva) (2006) Manual de fertilização das culturas. Ministério da Agricultura, do Desenvolvimento Rural e Pescas, Instituto Nacional de Investigação Agrária e das Pescas, Lisboa, Portugal

Mediavilla S, Escudero A, Heilmeier H (2001) Internal leaf anatomy and photosynthetic resourse-use efficiency: interspecific and intraspecific comparisons. Tree Physiol 21:251-259

Morales-Sillero A, Fernández JE, Ordovás J, Suárez MP, Pérez JA, Liñán J, López EP, Girón I, Troncoso A (2009) Plantsoil interactions in a fertigated 'Manzanilla de Sevilla' olive orchard. Plant Soil 319:147-162

Peña-Rojas K, Aranda X, Joffre R, Fleck I (2005) Leaf morphology, photochemistry and water status changes in resprouting Quercus ilex during drought. Funct Plant Biol 32:117-130

Pettigrew WT (2008) Potassium influences on yield and quality production for maize, wheat, soybean and cotton. Physiol Plant 133:670-681

Qiu S, Xie J, Zhao S, Xu X, Hou Y, Wang X, Zhou W, He P, Johnston AM, Christie P, Jin J (2014) Long-term effects of potassium fertilization on yield, efficiency, and soil fertility status in a rain-fed maize system in northeast China. Field Crops Res 163:1-9

Restrepo-Diaz H, Benlloch M, Navarro C, Fernández-Escobar R (2008) Potassium fertilization of rainfed olive orchards. Sci Hortic 116:339-403 
Rodrigues MA, Ferreira IQ, Claro AM, Arrobas M (2012) Fertilizer recommendations for olive based upon nutrients removed in crop and Pruning. Sci Hortic 142:205-211

Rosati A, Caporali S, Paoletti A (2015) Fertilization with N and $\mathrm{K}$ increases oil and water content in olive (Olea europaea L.) fruit via increased proportion of pulp. Sci Hortic 192:381-386

Saykhul A, Chatzissavvidis C, Therios I, Dimassi K, Chatzistathis T (2014) Growth and nutrient status of olive plants as influenced by foliar potassium applications. J Soil Sci Plant Nutr 14(3):602-615

Scherer HW, Mengel K (2007) Ullmann's agrochemicals. Fertilizers (Chapter 2), vol 3. Wiley, Weinheim

Shabala S, Pottosin I (2014) Regulation of potassium transport in plants under hostile conditions: implications for abiotic and biotic stress tolerance. Physiol Plant 151:257-279

Tan D, Jin J, Jiang L, Huang S, Liu Z (2012) Potassium assessment of grain producing soils in North China. Agric Ecosyst Environ 148:65-71
Therios I (2009) Olives. Crop production science in horticulture, vol 18. CABI International, Oxfordshire

von Caemmerer S, Farquhar GD (1981) Some relationships between the biochemistry of photosynthesis and the gas exchange of leaves. Planta 153:376-387

Walinga I, van Vark W, Houba V, van der Lee J (1989) Soil and plant analysis: part 7-plant analysis procedures. Wageningen Agricultural University, Wageningen

Zegaoui Z, Planchais S, Cabassa C, Djebbar R, Belbachir OA, Pierre Carol P (2017) Variation in relative water content, proline accumulation and stress gene expression in two cowpea landraces under drought. J Plant Physiol 218:26-34

Zhao S, He P, Qiu S, Jia L, Liu M, Jin J, Johnston AM (2014) Long-term effects of potassium fertilization and straw return on soil potassium levels and crop yields in northcentral China. Field Crops Res 169:116-122

Zörb C, Senbayram MS, Peiter E (2014) Potassium in agriculture: status and perspectives. J Plant Physiol 171:656-669 